DOI: https://doi.org/10.24127/ajpm.v10i4.4357

\title{
ANDROID-BASED MATHEMATICAL LEARNING MEDIA: ONLINE LEARNING ALTERNATIVES IN THE TIME OF THE COVID-19 PANDEMIC
}

\author{
Westi Bilda $^{1^{*}}$, Ahmad Fadillah ${ }^{2}$, Dian Nopitasari ${ }^{3}$ \\ 1,2,3 Pendidikan Matematika, Universitas Muhammadiyah Tangerang, Indonesia \\ *Corresponding author. \\ E-mail: $\quad$ westibilda24@gmail.com $^{1 *}$ \\ fadielalgebra4@gmail.com ${ }^{2)}$ \\ diannopitasari511@yahoo.com $^{31}$
}

Received 28 October 2021; Received in revised form 04 December 2021; Accepted 28 December 2021

\begin{abstract}
The main purpose of this research is to produce android-based learning media products on valid and practical trigonometric materials used.. The research carried out is development research with 4D models (define, design, development, dessimination). Participants in this study were students of class X SMK.. The data in the study was collected using a questionnaire, which consists of an expert validation questionnaire, and a student response questionnaire as a user. Based on the results of the analysis of research data conducted obtained a value of $75.50 \%$ for media experts and $75.60 \%$ for material experts with good categories. The next stage is a practicality test and questionnaire on a small scale and obtained a score of $75.17 \%$ with good and practical categories. So it was concluded that android-based learning media is feasible and practically used in mathematical learning.
\end{abstract}

Keywords: Android; Covid-19; Learning Media

\begin{abstract}
Abstrak
Tujuan utama penelitian ini adalah untuk menghasilkan produk media pembelajaran berbasis android pada materi trigonometri yang valid dan praktis digunakan. Penelitian yang dilaksanakan adalah penelitian pengembangan (Development Research) dengan model 4D (define, design, development, dessimination). Partisipan pada penelitian ini adalah siswa kelas X SMK. Data dalam penelitian ini dikumpulkan dengan menggunakan angket, yang terdiri dari angket validasi ahli, dan angket respon siswa sebagai pengguna. Berdasarkan hasil analisis data penelitian yang dilakukan diperoleh nilai 75.50\% untuk ahli media dan 75,60\% untuk ahli materi dengan kategori yang baik. Tahap berikutnya adalah tes kepraktisan dan kuesioner dengan skala kecil dan memperoleh nilai 75,17\% dengan kategori baik dan praktis. Jadi disimpulkan bahwa media pembelajaran berbasis android layak dan praktis digunakan dalam pembelajaran matematika.
\end{abstract}

Kata kunci: Android; Covid-19; Media Pembelajaran

This is an open access article under the Creative Commons Attribution 4.0 International License

\section{INTRODUCTION}

The development of science and technology has changed the paradigm and way of life of all human activities in various aspects of life. One of the most felt technological impacts today is in the field of information and education. One of them includes the activities of mathematical learning proccess in the midst of the current covid-19 pandemic. Goldschmidt (2020) states that the health crisis caused by the Covid-19 outbreak has pioneered online learning in unison. Bilda \& Fadillah (2020) mentions there are four ways that COVID-19 change the way we educate 
future generations. First, the worldwide education process is getting interconnected. Second, redefining educators' roles. Third, teaching the importance of life skills in the future. And, fourth, opening broader technological role in supporting education. Fadillah et al., (2021) the tsunami of online learning has occurred almost all over the world during the Covid-19 pandemic. Teachers and educators as an important element in teaching are required to make unprecedented massive migrations from face-to-face education to online education or distance education. Various creativity and innovations need to be done by all educators in the Covid-19 area that occurs almost all over the world today to determine the sustainability of the process of quality learning activities with the selection of the right learning methods and media. Saifulloh et al., (2012) this is in accordance with Government Regulation No. 19 of 2005 on National Standards of Education that teachers as educators must have academic qualifications and competencies as learning agents. Competencies as learning agents at primary and secondary education levels include Pedagogical, personality, professional, and social competencies. One element of Pedagogical competence is that teachers are able to develop and utilize media and learning resources. Therefore, teachers are required to be able to develop learning media in the learning process (Apsari \& Rizki , 2018).

The use of learning media can be adjusted to the characteristics and conditions of the school. Media defined as "all means of communication, whatever its format." In this sense, media include symbol systemsas diverse as print, graphics, animation, audio, and motion pictures. Technology is defined as "any object or process of human origin that can be used to convey media." In this sense, technology includes phenomena as diverse as books, films, television, and the Internet (O.D, 2014). Media is a communication intermediary that comes in many forms. Learning media is intended to enrich the learning experience using a variety of objects to facilitate learning purposes. Learning media can be referred to as a tool to expand the abilities of teachers and expand the abilities of students. Learning media also serves as a tool to strengthen important points in the subject matter so that the acquisition of learning outcomes increases. Strengthening lesson information with different media offers opportunities to strengthen learning without being seen over and over again for learners (Ghavifekr \& Rosdy, 2015). Setiyo et al., (2018) Learning media is a tool in the process of teaching and learning activities to increase the spirit and enthusiasm of students so that they follow the learning process. Setyadi \& Qohar (2017) the use of interesting learning media will increase students' motivation and interest in learning which will ultimately make students successfully understand the material provided. Benefits of using learning media according to Warsita (2018) Among others: laying concrete foundations for thinking and reducing verbalism, attracting students' attention, laying out the fundamentals that are essential for learning development, providing real experiences and fostering independent activities in students, fostering regular and sustainable fertilization, especially those related to daily life, assisting in the development of language skills, and adding variety in 
learning activities. It is also in line with opinions Anwar \& Anis (2020) which states that media is useful to make teaching more interesting so that it can foster learning motivation in students, clarify the meaning of teaching materials to be easier to understand so that teachers master the purpose of teaching well, make learning methods more varied, by combining verbal communication from teachers with other media so that students do not get bored, and make students more involved in learning activities, Not only listening, but also various other activities, such as observing, demonstrating, presentation, and others. Many learning media that can be applied and used in online learning as it is today, one of which is android-based learning media.

The use of Android-based learning media is one of the applications of 21 st century learning styles (Calimag et al., 2014). The use of this kind of learning media has the potential to help improve the academic performance of learners in the form of learning outcomes in the cognitive realm (Jabbour, 2014) and the learning motivation of learners (Hess, 2014). Li et al. ( Yektyastuti \& Ikhsan, 2016) The implementation of learning using smartphones and tablets can provide positive dam-pack to the cognitive, metacog-nitif, affective, and sociocultural dimensions. Smartphones and tablets have the power to transform the learning experience. This type of learning medium allows learners to learn unlimited by time and place with interesting applications (Meister et al., 2011). Huda (Setyadi \& Qohar, 2017) Android is one of the operating systems (OS) for smartphones or tablets based on Linux. Setyadi (2017) At the moment, Android has the largest number of users because it has several advantages in its operating system. Some of the advantages that android applications have according to Jihad \& Lasmanah (2019) Android applications in mathematics are very useful if used by learners to be used as other sources as an exercise in doing problems or understanding related materials presented. Mathematics is not an easy lesson if learners do not practice often. Android has the advantage that one of them can be repaired as needed. So that the material developed in the application can be added according to the needs of learners. Therefore, mobile learning is important to be applied to mathematical learning. Darussalam (Jihad \& Lasmanah, 2019) The use of android-based learning media can reduce a static atmosphere and can create an effective, interesting, interactive learning process and can generate learning motivation for learners.

Previous research conducted, Apsari \& Rizki (2018) states that android-based mathematical learning media on linear program materials is declared valid and practical so that it can facilitate students in the learning process both inside and outside the classroom; Hendriawan \& Septian (2019) the result of the research shows that the multimedia of mathematics education based on android developed by the media expert meets the Very Eligible category with the percentage reaching $81 \%$. Meanwhile, according to the material expert meets the Eligible category with a percentage of $65.83 \%$. Then for the effectiveness of multimedia education developed according to respondents meet the Eligible category with the percentage reached $74.1 \%$. So that the multimedia of mathematics education based on 
DOI: https://doi.org/10.24127/ajpm.v10i4.4357

Android is effectively used as a supporting multimedia of education for students who can use anytime and anywhere; Kocakoyun \& Bicen (2017) research results show that mobile applications will support education and increase motivation. The study supports that mobile apps improve academic achievement. It is rich in terms of materials and may be one of the applications that students can use for communication. The results also showed that mobile apps will support education and increase motivation. The study supports that mobile apps improve academic achievement. Based on the findings above, the purpose of this study is to produce products in the form of andorid-based learning media that are feasible and practical to be used as a form of online learning solutions and alternatives.

\section{METHOD}

The goal of this research is to produce android-based learning media products that are viable and practical to use. Methods used in research and development ( $R$ \&D) methods with a 4D model approach (define, design, development, dissemination). Participants to this study used students of SMK Avicena Tangerang Regency. This research process goes through stages: the defining stage, the planning stage, the development stage, and the dispersal stage. Development procedures presented in Table 1 .

Table 1. Research Development Procedures

\begin{tabular}{|c|c|c|}
\hline $\begin{array}{l}\text { Development } \\
\text { Stage }\end{array}$ & Activities & Expected Exterior \\
\hline Define & $\begin{array}{l}\text { 1. Final initial analysis } \\
\text { 2. Student analysis } \\
\text { 3. Task analysis } \\
\text { 4. Material analysis } \\
\text { 5. Learning objectives }\end{array}$ & $\begin{array}{l}\text { 1. Identified the needs of learning media } \\
\text { needed in online learning } \\
\text { 2. The need for learning media, especially } \\
\text { mathematics that can be used anytime and } \\
\text { anywhere } \\
\text { 3. Selected materials adapted to the } 2013 \\
\text { curriculum applicable in schools }\end{array}$ \\
\hline Design & $\begin{array}{l}\text { 1. Media selection } \\
\text { 2. Format selection } \\
\text { 3. Initial plan }\end{array}$ & $\begin{array}{l}\text { 1. Media selection is adjusted to the results of } \\
\text { material analysis that has been done in } \\
\text { accordance with the characteristics of } \\
\text { learners } \\
\text { 2. The establishment of a learning medium } \\
\text { that is ready to be validated by experts }\end{array}$ \\
\hline Development & $\begin{array}{l}\text { 1. Validation of learning } \\
\text { media by material } \\
\text { experts and media } \\
\text { experts } \\
\text { 2. Revisions and } \\
\text { improvements based } \\
\text { on expert comments } \\
\text { and suggestions }\end{array}$ & $\begin{array}{l}\text { At this stage produced the final form of } \\
\text { learning media after going through revisions } \\
\text { based on input from experts. }\end{array}$ \\
\hline Dessimination & $\begin{array}{l}\text { Conduct limited-scale } \\
\text { trials by users }\end{array}$ & $\begin{array}{l}\text { Obtained data on the practicality and } \\
\text { effectiveness of learning media developed }\end{array}$ \\
\hline
\end{tabular}


DOI: https://doi.org/10.24127/ajpm.v10i4.4357

The instruments used in this study are questionnaires. Data collection techniques through questionnaires performed during validation of material experts, media experts, and users. The quality of the products produced analyzed with measures adopted from opinion Apsari $\&$ Rizki (2018). The questionnaire used for validity assessment using the likert scale is the highest score of 5 and the lowest score of 1. Material expert validation assessment questionnaires and media experts are presented at table 2 and table 3.

Table 2. Material Expert Validation questionnaire

\begin{tabular}{|c|c|c|}
\hline No. & Aspects & Indicator \\
\hline 1 & $\begin{array}{l}\text { Quality } \\
\text { Content } \\
\text { Purpose }\end{array}$ & $\begin{array}{l}\text { a. Conformity with basic } \\
\text { competencies } \\
\text { b. learning objectives } \\
\text { c. Learning flow } \\
\text { d. Conformity of matter } \\
\text { e. Depth of material presented } \\
\text { f. Ease of understanding the } \\
\text { material } \\
\text { g. Quality of training } \\
\text { h. Accuracy of language use }\end{array}$ \\
\hline 2 & $\begin{array}{l}\text { Quality } \\
\text { Learning }\end{array}$ & $\begin{array}{l}\text { a. Clarity of instructions in } \\
\text { media use } \\
\text { b. Accuracy of training } \\
\text { feedback on the problem } \\
\text { c. Ease of learning } \\
\text { d. Means of interaction } \\
\text { between teachers and } \\
\text { students } \\
\text { e. Learning independently } \\
\text { f. The desire to study other } \\
\text { material with similar media }\end{array}$ \\
\hline
\end{tabular}

Table 3. Media Expert Validation questionnaire

\begin{tabular}{cll}
\hline No. & Aspects & Indicator \\
\hline 1 & Alignment & a. Color fusion \\
& & b. Ease of navigation \\
& & c. Clarity of instructions \\
2 & Balance & a. Placement of buttons \\
& & b. Writing layout \\
& Letter shape & a. Suitability of typeface \\
& & b. Suitability of font size \\
& & c. Variations in size and \\
4 & Color & d. Readability of text or \\
& & d. Background \\
\end{tabular}

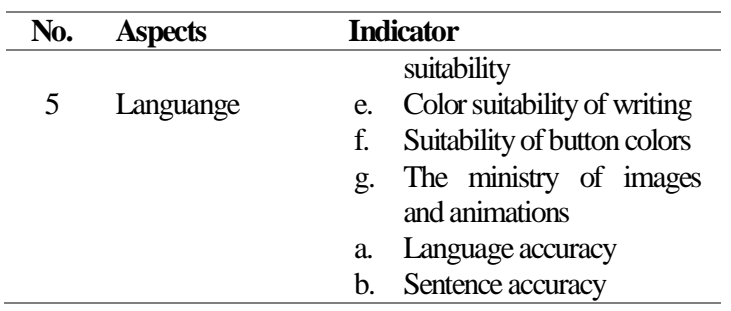

As for measuring the practicality of the product analyzed with measures adopted from those adopted from Pradipta (2017). The questionnaire is given to the user to assess the media used. From the results of the assessment of the student questionnaire will be analyzed so that it is seen that from the android-based learning media is feasible or not as reference material or learning media. Validation questionnaire by the user is presented in table 4 .

Table 4. Validation Questionnaire by User

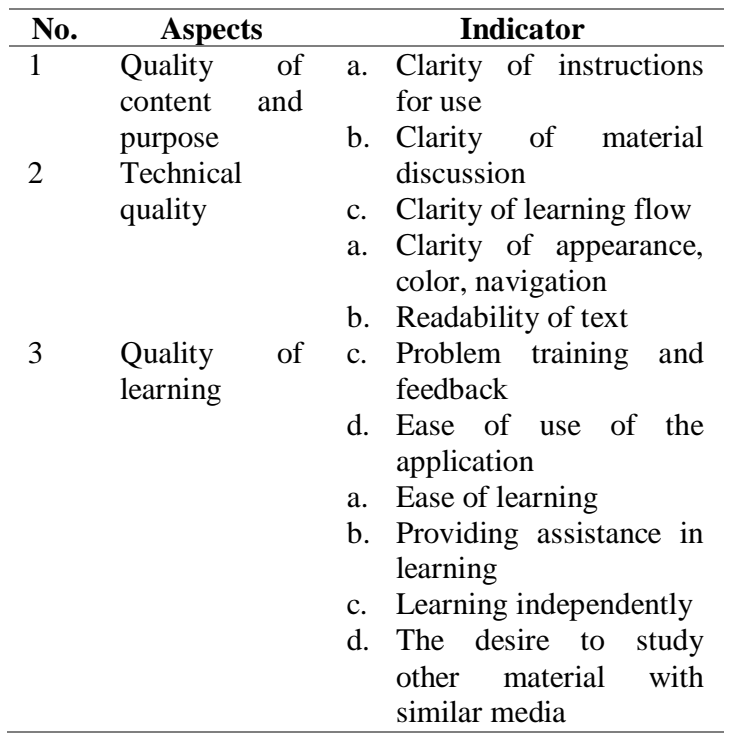

The data sources in this study resulted from material experts, media experts, and users. Qualitative data collected in this study is data obtained from the results of comments or suggestions from questionnaires assessed by experts, namely material experts and media experts for product validation and the results are used for 
revision. While the quantitative data obtained is the result of suspension from the questionnaire in the form of a description of the percentage of validity by experts and the practicality of the product by the user. This development research analysis technique is product validation analysis and practicality analysis students get from (Akdon \& Riduwan, 2013). Product validation criteria and product practicality are presented in Table 5 and Table 6.

Table 5. Product Validation Criteria

\begin{tabular}{ll}
\hline Score (\%) & Criteria \\
\hline $80<\mathrm{N} \leq 100$ & Very Worthy \\
$60<\mathrm{N} \leq 80$ & Worth \\
$40<\mathrm{N} \leq 60$ & Less Worthy \\
$20<\mathrm{N} \leq 40$ & Not worth it \\
$0<\mathrm{N} \leq 20$ & Very Unworthy \\
\hline
\end{tabular}

Table 6. Product practicality criteria

\begin{tabular}{ll}
\hline Score (\%) & Criteria \\
\hline $80<\mathrm{N} \leq 100$ & Very practical \\
$60<\mathrm{N} \leq 80$ & Practical \\
$40<\mathrm{N} \leq 60$ & Less Practical \\
$20<\mathrm{N} \leq 40$ & Impractical \\
$0<\mathrm{N} \leq 20$ & Very Impractical \\
\hline
\end{tabular}

\section{RESULTS AND DISCUSSION}

The purpose of this research is to produce products in the form of android-based learning media. This stage of research uses 4D methods (Define, Design, Developement, Dessimination). Assessment of the resulting product through the assessment of media experts and material experts. Here are the results of assessment and validation by experts which is in table 7 and table 8 :

Table 7. Material Expert Validation Results

\begin{tabular}{lll}
\hline Aspects & Persentage & Criteria \\
\hline $\begin{array}{l}\text { Quality of content and } \\
\text { purpose }\end{array}$ & $75.00 \%$ & Good \\
$\begin{array}{l}\text { Quality of Learning } \\
\text { Average }\end{array}$ & $76.00 \%$ & Good \\
\hline
\end{tabular}

Table 8. Media Expert Validation Results

\begin{tabular}{lll}
\hline Aspects & Persentage & Criteria \\
\hline Alignment & $76.50 \%$ & Good \\
Balance & $75.00 \%$ & Good \\
Letter shape & $74.50 \%$ & Good \\
Color & $76.00 \%$ & Good \\
Language & $73.00 \%$ & Good \\
\hline Average & $75.60 \%$ & Good \\
\hline
\end{tabular}

Based on table 7 and table 8 above obtained results of $75.50 \%$ and $75.60 \%$ respectively for media experts and experts of good and usable category materials. Products that have been declared valid by validators are tested to students to determine the response and level of practicality to the product. Here are the results of the assessment of the students against the products produced and presented in table 9 .

Table 9. Practicality Test results by users

\begin{tabular}{lll}
\hline Assessment Aspects & Persentage & Criteria \\
\hline Quality of content & $74.50 \%$ & Practical \\
and purpose & $75.00 \%$ & Practical \\
Technical quality & $76.00 \%$ & Practical \\
Quality of learning & $75.17 \%$ & Practical \\
\hline Average & $75.17 \%$ & Practical \\
\hline
\end{tabular}

Based on the results of the assessment of the response in students to android-based learning media obtained results from each aspect of assessment including on practical criteria (easy to use), obtained results with the average practicality test is $75.17 \%$ with practical criteria, which means that android-based learning media is practical and worth using. This is in accordance with previous research that states that bring android-based learning media learning media worthy of use in mathematical learning (Zakiy et al., 2018); The results showed that the UoS-oriented android-based Mathematics learning medium can 
improve student learning outcomes (Rohman et al., 2019).

Learning media research and development aims to produce androidbased learning media as an online learning solution and alternative during the Covid-19 pandemic. Development procedures in this research use research and development ( $\mathrm{R} \& \mathrm{D})$ research models with 4D methods (Define, Design, Development, Dissemination).

The define stage is the stage of establishing and determining the learning requirements that include learning objectives and restrictions on learning materials. The stages in this stage are: 1) The final initial analysis which includes the analysis of the applicable curriculum and in accordance with the basic competencies of the material. This curriculum analysis is necessary for a better learning process and adapted to the RPP and syllabus that applies in SMK Avicena Tangerang Regency before carrying out research related to the development of learning media. 2) The analysis of learners is a study to find out the characteristics of learners that include the ability, background of knowledge, and the level of cognitive development of learners. From the results of this analysis will later be used as a frame of reference in designing and developing learning media. 3) Task analysis is carried out to analyze the main tasks that must be mastered by learners in order to achieve minimal competence. The task in this learning is in the form of evaluation tests analyzed by teachers based on the learning objectives listed in the learning implementation plan with materials taught during the learning process so that minimal competencies are expected to be achieved or in accordance with expectations. 4) Material analysis is carried out to identify the material components to be taught to students, which are made in the concept map making it easier for students to learn. This stage is the identification of the main concepts that will be taught and arrange them systematically by detailing the concept of material in the form of a concept map. 5) The purpose of learning is to override the objectives of material analysis and task analysis into basic competencies expressed by behavior. The preparation of learning objectives or indicators of achievement of learning outcomes is based on basic competencies and indicators listed in those used in SMK Avicena Tangerang Regency.

The results of the analysis conducted at this stage, obtained the finding that the curriculum used in SMK Avicena is the 2013 curriculum and the material to be developed used by learning media is trigonometry in students of class X SMK Avicena with sub-material namely; The rules of the sinuses, the rules of cosine, the ratio of the area of the triangle, the ratio of two angles. After studying this trigonometric material it is expected that students are able to use the concept of trigonometry to solve problems related to trigonometry. The consideration of researchers taking this material is due to the time constraints available to create media. Based on curriculum analysis and observation can be identified basic competency formulation which further developed indicators from the material of mathematics subjects presented in Table 10. Based on the results of interviews conducted, the media that will be developed in this research is androidbased learning media. This media selection was done because it was found that the activities of the mathematical learning process at SMK Avicena 
DOI: https://doi.org/10.24127/ajpm.v10i4.4357

during the covid-19 pandemic were only limited to using applications such as zoom meetings and whatssapp, not yet using digital-based learning media. So that learning media is needed to support and support learning process activities during the covid-19 pandemic that can be accessed anytime and anywhere.

Table 10. Basic Competencies and Competency Achievement Index

\section{Basic Competencies (BC) \\ Competency Achievement Index (CAI)}

1. Show a happy attitude, confidence, internal motivation, critical attitude, cooperation, honesty and confidence in solving real problems

2. Demonstrate the ability to work together in solving trigonometric problems

3. Understand and define trigonometric multiplication formulas, select and apply in real problem solving and mathematics

4. Utilizing information from a real problem, creating models in the form of trigonometric functions and equations and using them in solving problems

The second step is the planning stage. At this stage, media plans are produced. The planning stage aims to design the developed media. The steps are as follows: 1) Media selection is adjusted to the results of the analysis of material that has been done in accordance with the characteristics of learners. Media selection is essential in relation to an efficient teaching and learning process and making students active, confident, and learning is no longer teacher-centered. The media used is in the form of Android applications that have been adapted to the purpose of learning and rules in the preparation of the correct learning media. 2) Selection of media formats is intended to design or design the content of learning media adapted to the learning materials and curriculum 2013 used. The selected media development format should be able to characterize Android applications such as containing images and a general summary of the teachertaught material. 3) The initial intended
1. Actively involved in trigonometric learning

2. Working together in group activities

3. Tolerant of different and creative problem-solving processes

4. Re-explaining the formulas of sine and cosine trigonometric multiplication

5. Restates the formula of sine and cosine trigonometric multiplication formulas design is a media design made before the trial.

The results at the design stage above researchers use android studio software to create learning media. Android studio was chosen because in this software there are many advantages that can help researchers create learning applications. Here is a sketch design of android-based learning media presented in Figure 1.

After the initial sketch is made, then the next stage of design is storyboarding and media implementation. This stage is to realize the design design in the form of sketches of design plans that have previously been made into real designs and are suitable for learning media. The software used is Android Studio 3.5 to support the content of the author's media to take pictures, make videos and summarize material for easy to understand. After the product design is made, the researcher continues the design by creating a storyboard. 
Storyboard is a sketch of a picture or storyboard that serves to convey a message or idea to be accepted by others more easily. Storyboard view in Figure 2 and Table 11.
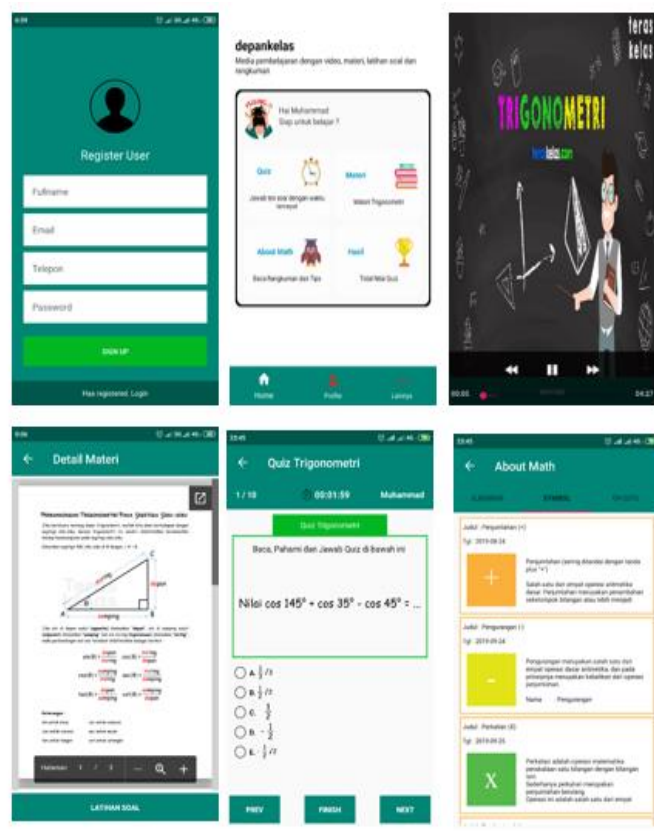

Figure 1. Android-Based Learning Media Sketch
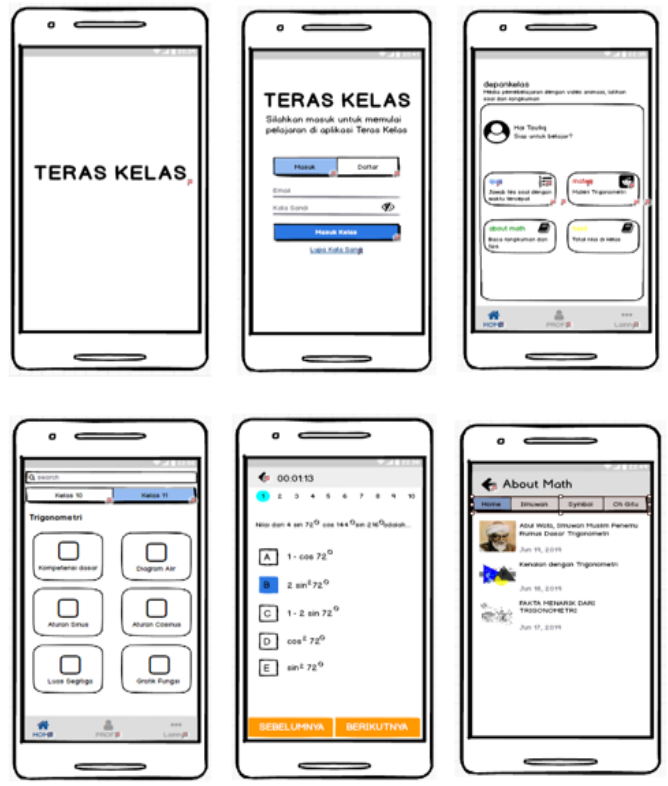

Figure 2. Android-Based Learning Media Design
Table 11. Storyboard on Android-Based Learning Media

\begin{tabular}{|c|c|}
\hline Button & Function \\
\hline Login & $\begin{array}{l}\text { The login button works to sign in to a } \\
\text { class terrace account }\end{array}$ \\
\hline Sign up now & $\begin{array}{l}\text { Sign up button for account listings on } \\
\text { the classroom terrace }\end{array}$ \\
\hline $\begin{array}{l}\text { Forgot the } \\
\text { password }\end{array}$ & $\begin{array}{l}\text { On this button when the user forgets } \\
\text { the old password then create a new } \\
\text { password }\end{array}$ \\
\hline Home & $\begin{array}{l}\text { This button if the user wants to return } \\
\text { to the original page }\end{array}$ \\
\hline Profile & $\begin{array}{l}\text { This button serves to view personal } \\
\text { data from class terrace users }\end{array}$ \\
\hline Other & $\begin{array}{l}\text { This button serves to see about the } \\
\text { application and logout }\end{array}$ \\
\hline Material & $\begin{array}{l}\text { This button aims to view videos, } \\
\text { materials and exercises }\end{array}$ \\
\hline Quiz & $\begin{array}{l}\text { This button will lead the user to test } \\
\text { some questions about the knowledge }\end{array}$ \\
\hline About Math & that has been obtained \\
\hline Results & $\begin{array}{l}\text { This button is to make it easier for } \\
\text { users about scientists, symbols, and } \\
\text { others }\end{array}$ \\
\hline & $\begin{array}{l}\text { This button aims to see the results of } \\
\text { quiz values }\end{array}$ \\
\hline
\end{tabular}

The third stage is the development stage. After the sketch design and final design of the learning media, the learning media is validated by material experts and media experts by providing questionnaires arranged based on indicators adapted from Yahya (Apsari \& Rizki, 2018). Validation by media experts aims to get information, criticism, and suggestions that the media developed into a quality product in terms of appearance and language, while the purpose of material expert validation is to know the accuracy and appropriateness of aspects of the content of the material content of the product developed whether it is in accordance with the needs or not. The validation results of experts are obtained by a percentage of $75.50 \%$ and $75.60 \%$ respectively for media experts and experts of good and usable category materials. Suggestions from validators are used as a foundation in the revision of learning media development results carried out. Media views before and after revision can be seen in Figure 3. 

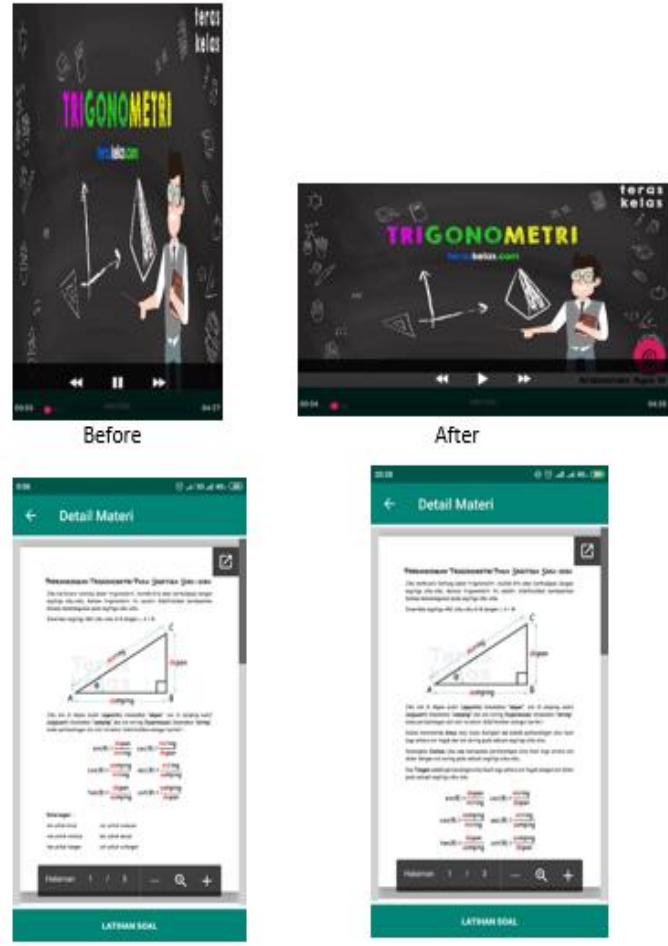

Before

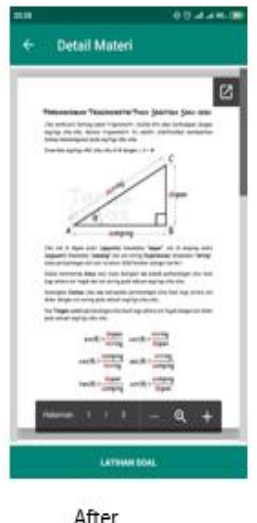

After

Figure 3. Before and after the revision

The fourth stage is disseminate. After the media is validated and revised according to the advice and input of media experts and material experts, android-based learning media is piloted on a limited scale to smk Aicena students as users to know the level of practicality of media when used. To find out the response and response of students as users used a questionnaire adapted from Pradipta (2017) with indicators of the quality of content and purpose, quality of techniques, and quality of learning. Based on the results of the assessment of responses and responses in students to android-based learning media obtained results from each aspect of assessment included in the category of practical (easy to use), with an average score of $75.17 \%$ which means that android-based learning media is practical and worth using. The implementation of a limited scale test can be seen in Figure 4.

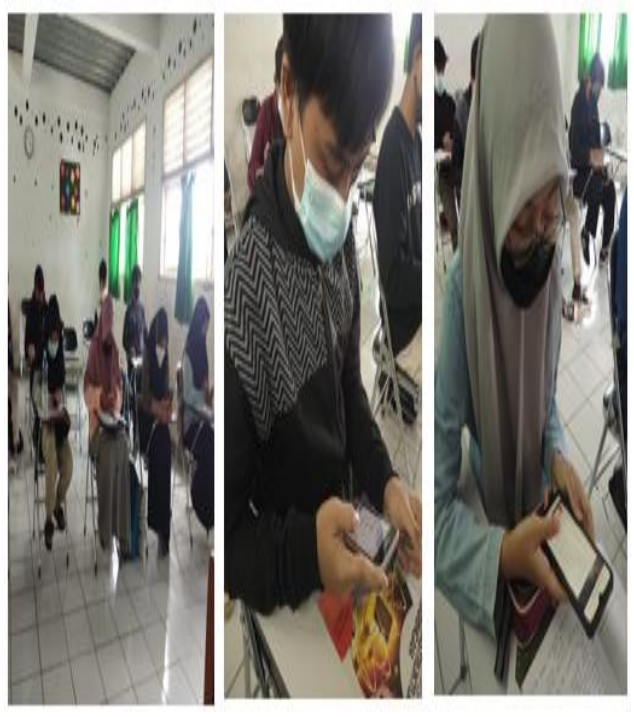

Figure 4. Limited Scale Test by user

Previous research related to this study include: Hamdani \& Priatna (2021) concluded that: 1) android-based learning media is declared valid; 2) Practical android-based learning media. Thus the android-based mathematical learning media developed can be used by teachers and students as learning in school or learning independently at home; Rusdiansyah \& Leonard (2020) the results of the study showed that the developed media is feasible and qualified for use as a learning medium motion graphic mathematics based on Android in students class V elementary school semester 1 . This is seen from the results of validation by media experts of $87.5 \%$ declared good. Then the validation results by material experts of $87.5 \%$ were declared good. After a validation test by experts we do a trial to a small group to get $95 \%$ results with very good categories. Based on these results it can be concluded that this Android-based mathematical Motion Graphic learning media is feasible to use in learning; Purnomo \& Suparman (2020) development of android-based learning media in elementary mathematics education courses with 
valid categories. The results of media development are as follows a). Media validation by experts gets an average of 4. 07 which has a valid category, b). The result of the small readability test resulted in a valid rating of 3.92; Nuryadi (2019) the results of research showed that android-based mobile learning mathematics learning media meets valid, practical and effective criteria in terms of problem solving capabilities.

The results of this study are expected to contribute and solutions in the use of learning media in smk Avicena in the midst of the current Covod-19 pandemic. The use of learning media can help students understand mathematical concepts. There is another cause of other factors that become low student learning outcomes are students who respond less to the material provided by teachers. Students are more silent in responding to learning materials during the process of teaching and learning activities. Students are busy themselves with gadgets, which students have only for entertainment such as telephone, SMS, music, chat, and others. Solutions that can be used to make it easier for students to understand mathematical concepts are by utilizing smartphones for students' learning facilities both inside and outside the classroom. This can provide a different experience in the learning process for students this learning medium presents an evaluation tool to the extent to which students understand the mathematical concepts provided as an exercise. Providing students with new experiences, students' opportunities to relearn less mastered material anywhere and anytime. The use of Android-based learning media certainly creates a new atmosphere in math learning, it is expected that the presence of this learning media has a positive influence on students' learning outcomes.

The limitations experienced by researchers in conducting research times include: 1) Programming languages are still very limited so that researchers have not been able to explore more deeply to create more interesting templates, 2) This research is only limited to small group trials, because if using large groups can take a long and long time, 3) The time it takes is relatively long if discussing all trigonometric materials into learning media, 4) The study did not examine the influence of media on students.

\section{CONCLUSION AND SUGGESTION}

Based on the results of data analysis and discussion on this study it was concluded that android-based learning media developed feasible and practical for use in mathematical learning. Based on validation results by experts obtained results by $75.50 \%$ for media experts and $75.60 \%$ for materials with good and decent categories. Based on small-scale test results by students of SMK Avicena as users obtained a result of $75.17 \%$ with good and practical categories. Android-based learning media is expected to be one of the solutions and alternatives to mathematical learning in the midst of the covid-19 pandemic. Suggestions that can be conveyed based on the results of research on the development of android-based learning media are as follows: 1) Learning media needs to be improved and developed using other software such as scholoogy-based $\mathrm{e}$ learing, android, sparkoll videoscrab, and others; 2) Non-limited trigonometry materials only, but can be used in other materials adapted to the applicable 
curriculum; and 3) It is necessary to test on a larger scale to get more optimal results.

\section{REFERENCES}

Akdon, \& Riduwan. (2013). Rumus dan Data dalam Analisis Statistika. Bandung: Alfabeta.

Anwar, S., \& Anis, M. B. (2020). Pengembangan Media Pembelajaran Matematika Berbasis Adobe Flash Profesional pada Materi Sifat-Sifat Bangun Ruang. Jurnal Pendidikan Matematika (Kudus), 3(1), 83-98. https://doi.org/10.21043/jpm.v3i1. 6940

Apsari, P. N., \& Rizki, S. (2018). Media Pembelajaran Matematika Berbasis Android Pada Materi Program Linear. AKSIOMA: Jurnal Program Studi Pendidikan Matematika, $\quad 7(1), \quad 161$. https://doi.org/10.24127/ajpm.v7i1. 1357

Bilda, W., \& Fadillah, A. (2020). An Analysis of Students in Independent Learning of Analytic Geometry During the COVID-19 Pandemic. JTAM (Jurnal Teori Dan Aplikasi Matematika), 4(2), 166-172.

https://doi.org/10.31764/jtam.v4i2. 2575

Calimag, J. N. V., Miguel, P. A. G., Conde, R. S., \& Aquino, L. B. (2014). Ubiquitous Learning Environment Using Android Mobile Aplication. International Journal of Research in Engineering \& Technology.

Fadillah, A., Sukmawati, R., \& Rahardjo, S. (2021). Analysis of Student Digital Literacy In Linear Algebra Courses During The
Covid-19 Pandemic. AKSIOMA: Jurnal Program Studi Pendidikan Matematika, 10(2), 1206-1212. https://doi.org/10.24127/ajpm.v10i 2.3704

Ghavifekr, S., \& Rosdy, W. A. W. (2015). Teaching and learning with technology: Effectiveness of ICT integration in schools. International Journal of Research in Education and Science, 1(2). https://doi.org/10.21890/ijres.2359 6

Goldschmidt, K. (2020). The COVID19 Pandemic: Technology use to Support the Wellbeing of Children. Journal of Pediatric Nursing, 53, 88-90.

https://doi.org/10.1016/j.pedn.2020 .04 .013

Hamdani, M. F., \& Priatna, N. (2021). Pengembangan Media Pembelajaran Matematika Berbasis Android untuk Siswa SMP/MTs dan SMA/MA. JURING (Journal for Research in ..., 4(4), 163-170. http://ejournal.uinsuska.ac.id/index.php/juring/article /view/12795

Hendriawan, M. A., \& Septian, A. (2019). Pengembangan JiMath Sebagai Multimedia Pembelajaran Matematika Berbasis Android Untuk Siswa Sekolah Menengah Atas. IndoMath: Indonesia Mathematics Education, 2(1), 4552.

https://doi.org/10.30738/indomath. v2i1.2785

Hess, S. (2014). Digital Media and Student Learning: Impact of Electronic Books on Motivation and Achievement. New England Reading Association Journal. 
Jabbour, K. K. (2014). An analysis of the effect of mobile learning on lebanese higher education. Informatics in Education. https://doi.org/10.15388/infedu.20 14.01

Jihad, A., \& Lasmanah, A. (2019). Pembelajaran matematika berbasis android untuk meningkatkan kemampuan komunikasi matematika di SMP. Jurnal Analisa, 5(2), 199-205. https://doi.org/10.15575/ja.v5i2.68 84

Kocakoyun, S., \& Bicen, H. (2017). Development and evaluation of educational android application. Cypriot Journal of Educational Sciences, 12(2), 58-68. https://doi.org/10.18844/cjes.v12i2 .1938

Meister, J. C., Kaganer, E., \& Von Feldt, R. (2011). 2011: The year of the media tablet as a learning tool. $T$ and D, 65(4), 28-31.

Nuryadi Nuryadi. (2019). Pengembangan Media Matematika Mobile Learning Berbasis Android ditinjau dari Kemampuan Pemecahan Masalah. Jurnal Pendidikan Surya Edukasi, 5(1), 1-12.

https://doi.org/https://doi.org/10.37 729/jpse.v5i1.5662

O.D, O. (2014). Relevance of Educational Media and Multimedia Technology for Effective Service Delivery in Teaching and Learning Processes. IOSR Journal of Research \& Method in Education (IOSRJRME).

https://doi.org/10.9790/738804214851

Pradipta, K. A. (2017). Pengembangan Media Pembelajaran Interaktif
Berbasis Adobe Flash Pada Mata Pelajaran Prakarya Dan Kewirausahaan Materi Elektro Listrik Untuk Kelas Xi Mipa Dan Ips Di Sma Negeri 3 Singaraja. Jurnal Pendidikan Teknologi Dan Kejuruan, 14(2). https://doi.org/10.23887/jptkundiksha.v14i2.11107

Purnomo, E. A., \& Suparman, S. (2020). Pengembangan Media Pembelajaran Berbasis Android pada Matakuliah Pembelajaran Matematika SD. Journal of Medives: Journal of Mathematics Education IKIP Veteran Semarang, $4(1), \quad 187$. https://doi.org/10.31331/medivesve teran.v4i1.960

Rohman, A. A., Ismail, M., \& Siswanah, E. (2019). Media Pembelajaran Matematika SMP Berbasis Android Berorientasi UoS untuk meningkatkan Hasil Belajar Siswa. Square: Journal of Mathematics and Mathematics Education, 1(1), 19-26. https://doi.org/10.21580/square.20 19.1.1.4057

Rusdiansyah, S., \& Leonard. (2020). Pengembangan Media Pembelajaran Motion Graphic Matematika Berbasis Android pada Siswa Kelas V SD Semester 1. Jurnal Pendidikan Dan Pembelajaran Dasar, 7(2), 135144.

https://doi.org/https://doi.org/10.24 042/terampil.v7i2.6996

Saifulloh, M., Muhibbin, Z., \& Hermanto, H. (2012). Strategi Peningkatan Mutu Pendidikan Di Sekolah. Jurnal Sosial Humaniora, 5(2), 206-2018. https://doi.org/10.12962/j24433527 .v5i2.619 
DOI: https://doi.org/10.24127/ajpm.v10i4.4357

Setiyo, E., Zulhermanan, Z., \& Harlin, H. (2018). Pengembangan Media Pembelajaran Berbasis Flash Flip Book pada Mata Kuliah Elemen Mesin 1 di Program Studi Pendidikan Teknik Mesin Universitas Sriwijaya. INVOTEK: Jurnal Inovasi Vokasional Dan Teknologi, 18(1). https://doi.org/10.24036/invotek.v1 $8 \mathrm{i} 1.171$

Setyadi, D. (2017). Pengembangan Mobile Learning Berbasis Android Sebagai Sarana Berlatih Mengerjakan Soal Matematika. Satya Widya, 33(2), 87-92. https://doi.org/10.24246/j.sw.2017. v33.i2.p87-92

Setyadi, D., \& Qohar, A. (2017). Pengembangan Media Pembelajaran Matematika Berbasis Web Pada Materi Barisan Dan Deret. Kreano, Jurnal Matematika Kreatif-Inovatif, 8(1), 1-7. https://doi.org/10.15294/kreano.v8i 1.5964

Warsita, B. (2018). Mobile Learning Sebagai Model Pembelajaran Yang Efektif Dan Inovatif. Jurnal Teknodik, 14(1), 62-73. https://doi.org/10.32550/teknodik.v $14 \mathrm{i} 1.452$

Yektyastuti, R., \& Ikhsan, J. (2016). Pengembangan Media Pembelajaran Berbasis Android pada Materi Kelarutan. Jurnal Inovasi Pendidikan IPA, 2 (1), 2016, 88-99.

Zakiy, M. A. Z., Muhammad, S., \& Farida. (2018). Pengembangan Media Android dalam Pembelajaran Matematika. TRIPLE S:Jourals of Mathematics Education, 1(2), 87-96. 